\title{
Screened Women
}

\section{Brian Bergen-Aurand}

As this issue of Screen Bodies went into production, the 2016 Democratic National Convention in Philadelphia, Pennsylvania, was concluding, and Vogue published a short online piece on Hillary Clinton's sartorial choices for her acceptance speech. While Clinton had often worn brighter, bolder colors and styles for her major appearances, on this evening she donned an ivory suit-a simple canvas against which to continue painting an image of the woman behind the candidacy. At the same time, the Internet continued to disseminate more negative reviews of the rebooted Ghostbusters (2016) - starring Melissa McCarthy, Kristen Wiig, Kate McKinnon, and Leslie Jones, directed by Paul Feig, written by Katie Dippold and Paul Feig. I think the film is (pace Lucille Ball) funny and brave. It hilariously reverses many sexist tropes and assumptions out of mainstream Hollywood films; it is crude and inappropriate in the best of ways; and responses to it-especially patriarchal, masculinist, heteronormative, and racist ones - continue to demonstrate the importance of critical comedic revisions for feminist interruptions of established paradigms. Meanwhile, in connection with another popular culture arena, I was listening to a report that the National Basketball Association dropped its fines against Women's National Basketball Association players supporting Black Lives Matters through ongoing on court protests. Since 9 July, teams from different cities have gone through their pregame warm-ups wearing shirts reading "Black Lives Matter"; an image of the Dallas, Texas, police shield; or the names of Alton Sterling and Philando Castile-black men recently killed by police officers - or simply solid black shirts in protest of the ongoing gun and police violence in the United States. Continued pressure from sports writers, activists, team owners, other male and female players, and fans has led the league to cancel the fines and switch to a position of publically supporting players' protest actions. Finally, reports about the active transmission of Zika virus at the Olympics in Brazil and throughout a neighborhood in Miami, Florida, recommended pregnant women or women wanting to become pregnant survey the information at the Centers for Disease Control and Prevention website. We might all spend some time attending to the images of women and families presented on those pages. What do they suggest?

This issue of Screen Bodies is especially focused on screened women and girls. We had not sought this focus on female embodiment, its display, and its 
effects but found the articles collected here developing a certain regard for the situations, images, and affects of those screened bodies. Sol Neely discusses abjection, allegory, and the film Deadgirl (Marcel Sarmiento and Gadi Harel, 2008) to open questions of ethical relations among humans and nonhumans, complicating the line between them in the process. Steen Ledet Christiansen explores cinesthetic pain and our responses to it through scenes of human/ animal body transformation in Black Swan (Darren Aronofsky, 2010). As transformation, pain, and becoming are linked in the film, so are the embodied responses of filmgoers linked to the effects of those screened transitions through a new encounter with biopower and its overcoming. Eliza Deac traces the relation between genre and gender from the Romantics to today in her study of one of the earliest hypertext fictions, Shelley Jackson's Patchwork Girl (1995), where an engagement with the tensions between monstrosity and harmony calls us to rethink our engagement with the multiple texts (screen and otherwise) of corporeality. Finally, Akkadia Ford returns to the problems of trans representation in the film Dallas Buyers Club (Jean-Marc Vallée, 2013) and raises issues of temporal displacement, narrative development and characterization, and the connections between the "fallen woman" film and the "trans film" across the history of mainstream cinema. Screening the female body may especially provoke questions of the line between human bodies and their opposites and about the relation between screening female bodies and screening transformation. Without intending to do so, these articles produce a portfolio of screening the female, the feminine, and femininity on edge and in transformation. Brought together with our reports on Genital Call and Genitals on Trial by Giegold and Weiß and the Inaugural Scottish Queer International Film Festival, as well as reviews of books and other media, this issue of Screen Bodies calls for a reexamination of how we divide and classify our bodies by gender and genre and the effects such divisions provoke.

With volume 2 (2017), Screen Bodies introduces a new section called Screen Capture, which will feature a collection of shorter articles on a single subject. The goal of this new section is to provide a glimpse into an ongoing conversation on a topic rather than a unified argument about a particular concept or issue. The first Screen Capture focuses on Queering the Middle East and North Africa on Screen, with considerations by and about images and effects of screen bodies from the region. The articles collected in this section provoke new ways of responding not only to these mediated corporealities but also to questions of local, national, transnational, regional, and global cinemas. Forthcoming are also separate articles on Iranian photography, small-screen Asian feminism, American underground film bodies, and disability comedy. Our second Screen Capture looks to focus on Screening Trans Bodies across Medias and will appear in 2018. With these new focused issues and regular sections, Screen 
Bodies seeks to increase its role in ongoing debates over embodied experience, perception, and display.

Brian Bergen-Aurand teaches in the English Department at Bellevue College, Washington, where he specializes in film, ethics, and embodiment. He is the founder and editor of Screen Bodies journal, the editor of Comedy Begins with Our Simplest Gestures: Levinas, Ethics, and Humor (2017) and Transnational Chinese Cinema, Corporeality, Desire, and the Ethics of Failure (2014, with Mary Mazzilli and Hee Wai Siam), and the author of Cinematic Provocation: Ethics, Justice, Embodiment, and Global Film (forthcoming 2017). Currently, he is developing (with Andrew Grossman) an encyclopedia of Global Queer Cinema.

\section{Filmography}

Aronofsky, Darren. 2010. Black Swan. USA.

Feig, Paul. 2016. Ghostbusters. USA/Australia.

Sarmiento, Marcel and Gadi Harel. 2008. Deadgirl. USA.

Vallée, Jean-Marc. 2013. Dallas Buyers Club. USA. 